ISSN 0258-7122

Bangladesh J. Agril. Res. 33(3) : 623-629, December 2008

\title{
EFFECT OF DURATION OF WEED COMPETITION AND WEED CONTROL ON THE YIELD OF INDIAN SPINACH
}

\author{
M.S.A. $\operatorname{KHAN}^{1}$, M. A. HOSSAIN ${ }^{2}$, M. NURUL ISLAM ${ }^{3}$ \\ S.N. MAHFUZA ${ }^{4}$ AND M.K UDDIN ${ }^{5}$
}

\begin{abstract}
Field experiments were conducted at the research farm of Bangladesh Agricultural Research Institute, Joydebpur during kharif-1 (March to July) seasons of 2005 and 2006 to identify the critical period of crop-weed competition for Indian spinach. Major weed species were Paspalurn commersoni, Echinochlaa crusgalli. Lie nv/nc india. Cyanotis axillaris and Cyperus rotundus. The lowest weed dry matter was $76.3 \mathrm{~g} \mathrm{~m}^{-2}$ in 2005 and $101.60 \mathrm{~g} \mathrm{~m}^{-2}$ in 2006 from the plots weeded up to 40 days after transplanting (DAT). The highest yields were obtained (74.82 t ha in 2005 and $48.48 \mathrm{t}$ ha in 2006) from the weed free plots. The fresh yield of Indian spinach did not vary among no weeding upto 20, 30 and 40 DAT in 2006. But weeded plot upto 30 and 40 DAT produced identical yield in 2005. Maximum BCR (4.52) was obtained from weeded plots upto 30 DAT in 2005 but BCR (2.60) was same from weeded upto 30 and 40 DA F in 2006. On an average, highest BCR (3.55) was recorded from weeding upto 30 DAT. Results revealed that the critical period of crop weed competition lies between 20 and 30 DAT and two times hand weeding would be necessary within 30 DAT for maximum benefit.
\end{abstract}

Key Words: Crop-weed competitions, critical period, weed management and Indian spinach.

\section{Introduction}

Indian spinach (Basella alba) is one of the important summer vegetables in Bangladesh. It is a popular and high nutritious leafy vegetable during kharif season. It contains $0.12 \mathrm{mg}$ calcium, $1.2 \mathrm{mg}$ iron, $0.08 \mathrm{mg}$ thiamine and $1686 \mathrm{IU}$ carotene (Anonymous, 2000). However, the average yield of this vegetable in this country is low due to improper use of fertilizer, poor weed control, etc. Since Indian spinach is cultivated during kharif season, during that time weeds also emerge and grow vigorously and compete with the crop for nutrients, space and solar radiation (Nicto et al., 1968) resulting in yield reduction. The reduction in yield of some vegetables caused by the uncontrolled growth of weeds estimated 49\% in cauliflower (Porwal and Singh, 1993). 80\% in okra (Singh et al., 1993) and $91 \%$ in onion (Singh and Singh, 1994). At the beginning of the growing

1, 2 \& 3 Agronomy Division, BARI, Joydebpur. Gazipur. ${ }^{4}$ Regional Agricultural Research Station, BARI, Jamalpur and ${ }^{5}$ Regional Agricultural Research Station, BARI, Ishurdi, Bangladesh. 
season, the requirement for growth resources is small enough that both the crop and weeds can co-exist without affecting each other. With the advancement of growing season, once weeds begin to deprive the crop and the yield potential can be negatively impacted. The knowledge of critical period of crop-weed competition is a pre-requisite for a good harvest. The critical period of weed is the portion of the life cycle of a crop during which it must be kept weed-free to prevent yield loss due to weed interference (Martin el al., 2001). Since, information on effect of weed on Indian spinach vine yield is inadequate in Bangladesh, therefore, the study was undertaken to identify the critical period of crop-weed competition for getting maximum and economic yield of Indian spinach.

\section{Materials and Method}

Field experiments were conducted at the research farm of Bangladesh Agricultural Research Institute, Joydebpur during kharif-I season from March to June of 2005 and 2006. The soil was silty clay loam with pH 6.3 belonging to agro-ecological zone 28 . The soil contained $0.8 \%$ organic matter, $0.035 \%$ total $\mathrm{N}$, $8.02 \mu \mathrm{g}$ available P. $0.18 \mathrm{meq} / 100 \mathrm{~g}$ soil exchangeable $\mathrm{K}$ and $10.0 \mu \mathrm{g}$ available sulphur. The total rainfall during the crop-growing period was $344.6 \mathrm{~mm}$ in 2005 and $840.6 \mathrm{~mm}$ in 2006. Average of 10 days interval, rainfall during growing season is given in Table 1 . The treatments are no weeding $\left(T_{1}\right)$, no weeding upto 40 days after transplanting (DAT) then weeding 2 times $\left(\mathrm{T}_{2}\right)$, no weeding upto 30 DAT then weeding 2 times ( $\left.T_{3}\right)$, no weeding upto 20 DAT then weeding 2 times $\left(T_{4}\right)$, weed free through out the growing period. 6 times weeding $\left(T_{5}\right)$, weeding upto 20 DAT with 2 times $\left(\mathrm{T}_{6}\right)$, weeding upto 30 DAT with 2 times $\left(\mathrm{T}_{7}\right)$ and weeding upto 40 DAT with 3 times $\left(\mathrm{T}_{8}\right)$. The trial was set up in randomized complete block design with three replications. The unit plot size was $3.0 \mathrm{~m} \times$ 4.5rn. The crop was fertilized with 70-15-45-15 kg NPKS per ha in the fbrm of urea, triple super phosphate, muriate of potash and gypsum, respectively. In addition, 5 ton scowdung per ha was applied during final land preparation. One third of $\mathrm{N}$ and full dose of $\mathrm{P}, \mathrm{K}$, and $\mathrm{S}$ were applied at the time of final land preparation. The remaining two thirds of $\mathrm{N}$ was top-dressed in two equal splits at 20 and 40 DAT, after weeding. The test variety was BARI Puishak-1. Seedlings of 21 days old were transplanted in the field on 30 March. 2005 and 10 April, 2006 at $45 \mathrm{~cm} \times 30 \mathrm{~cm}$ spacing. Three irrigations were applied, once immediately after transplanting, the others at 20 and 40 DAT. Rovral 50 WP @ $20 \mathrm{~g} / 10$ liter of water was sprayed at 50 DAT to control Cercospora leaf spot. The vine was harvested from 25 April to 20 June in 2005 and 5 May to 16 July in 2006. Data on number and kinds of weeds, dry matter of weeds upto 60 DAT and young vine yield were recorded. Weed control efficiency (WCE) was calculated by using the formula: WCI (DMC-DMT)/DMC X 100. Where. DMC = weed dry matter production in unxeeded control and, DMT $=$ weed dry matter production 
in weed managed treatment. Collected data were analyzed statistically with the help of MSTAT statistical package. The means were separated by least significant difference (LSD) test.

Table 1. Rainfall distribution during the growing period of Indian spinach at Joydehpur in 2005 and 2006.

\begin{tabular}{l|l|l|l}
\hline Month & Duration (days) & \multicolumn{2}{c}{ Rainfall (mm) } \\
\cline { 3 - 4 } & & 2005 & 2006 \\
\hline April & $0-10$ & 26.6 & 58.6 \\
& $11-20$ & 29.1 & 13.2 \\
& $21-31$ & 20.2 & 23.1 \\
May & $0-10$ & 34.3 & 78.6 \\
& $11-20$ & 50.7 & 105.6 \\
\multirow{3}{*}{ June } & $21-31$ & 62.1 & 280.8 \\
& $0-10$ & 16.4 & 194.2 \\
& $11-20$ & 35.2 & 74.6 \\
July & $21-31$ & 70.0 & 55.0 \\
& $0-10$ & 175.2 & 85.2 \\
& $11-20$ & 173.2 & 50.0 \\
\hline
\end{tabular}

\section{Results and Discussion}

Weed species \& their relative density: Weed species and their relative density in different treatments are presented in Table 2. The weeds flora infesting the Indian spinach field were Paspalum commersonii (Gaicha), Echinochloa crusgalli (Shyma), Digitaria sanguinalis (Anguli), Cyanotis axillaris (Kanainala), Eleusine indica, Cyperus rotundus (Vedile), Paspalum distichurn (Gitagrass), Portulaca oleracea (Nunia), Cynodon dactylon (Durba), Eclipta alba (Keshuti), Alternanthera philoxeroide (Maloncha), Alternanthera sessilis (Chanchi), Heliotropiurn indicum (Hatishur), Arnaranthus viridis (Shaknoty) and Jussiaea decurrens (Panilong). Among the weed species, Paspalum commersonii, Echinochloa crusgalli, Cyanotis axillaris and Cyperus rotundus were the major weeds. The relative density of the major weed species among the treatments ranged from 8.8 to 28.2, 28.3 to 63.9 , and 9.3 to 19.2 and 4.4 to $16.1 \%$, respectively. Portulaca oleracea, Eelipta alba, Alternanthera sessilis and Heliotropium indicum occured in lesser number in 2005. During 2006, Paspalum comrnersonhi. Echinochloa crusgalli, Eleusine indica, and Cyperus rotundus were found as major weeds with their relative density among the different treatments ranged from 0.3 to $14.0,18.6$ to $44.0,1.6$ to 23.3 and 10.2 to $28.1 \%$, respectively. Portulaca oleracea, Eclipta, Amaranthus viridis, Heliotropium indicum and Jussiaea decurrens occured in lesser number. 
Table 2. Weed species and their relative density (\%) in different treatments of indian spinach fields during 2005 and 2006.

\begin{tabular}{|c|c|c|c|c|c|c|c|c|c|c|c|c|c|c|c|c|}
\hline \multirow[t]{3}{*}{ Weed species } & \multicolumn{16}{|c|}{ Treatments } \\
\hline & \multicolumn{2}{|r|}{$\mathrm{T}_{1}$} & \multicolumn{2}{|c|}{$\mathrm{T}_{2}$} & \multicolumn{2}{|c|}{$\mathrm{T}_{3}$} & \multicolumn{2}{|r|}{$\mathrm{T}_{4}$} & \multicolumn{2}{|c|}{$\mathrm{T}_{5}$} & \multicolumn{2}{|c|}{$\mathrm{T}_{6}$} & \multicolumn{2}{|c|}{$\mathrm{T}_{7}$} & \multicolumn{2}{|c|}{$\mathrm{T}_{8}$} \\
\hline & 2005 & 2006 & 2005 & 2006 & 2005 & 2006 & 2005 & 2006 & 2005 & 2006 & 2005 & 2006 & 2005 & 2006 & 2005 & 2006 \\
\hline Paspalum commersoni & 28.2 & 3.9 & 13.7 & 0.3 & 18.3 & 4.0 & 17.9 & 13.9 & 27.3 & 5.2 & 8.8 & 9.4 & 19.6 & 14.0 & 14.2 & 12.3 \\
\hline Echinochloa crus gal/i & 29.1 & 29.1 & 36.6 & 33.5 & 48.2 & 44,0 & 37.2 & 22.7 & 34.2 & 19.6 & 63.9 & 47.6 & 28.3 & 18.6 & 49.3 & 31.0 \\
\hline Digitaria sanguinalis & 2.1 & 13.4 & - & - & 1.1 & 8.4 & 0.3 & 12.9 & 3.5 & 9.3 & 2.0 & 4.7 & - & - & 4.9 & 8.0 \\
\hline Cyariotis axillaris & 12.8 & 13.4 & 19.2 & - & 9.3 & 6.8 & 11.1 & 6.2 & 13.4 & 4.6 & 14.1 & 14.8 & 13.9 & 7.6 & 10.2 & 6.9 \\
\hline Eleusine indica & 3.9 & 1.6 & 1.3 & 23.3 & 1.9 & 5.0 & 4.5 & 3.6 & 3.9 & 15.0 & 2.4 & 5.5 & 0.9 & 5.5 & 4.0 & 4.2 \\
\hline Cyperus rotundus & 10.9 & 14.2 & 13.0 & 24.6 & 5.0 & 15.8 & 11.1 & 22.2 & 10.8 & 28.1 & 4.4 & 10.2 & 16.1 & 20.3 & 9.3 & 2L1 \\
\hline Paspalurn distichum & 1.9 & 9.4 & 4.9 & 5.4 & 3.7 & - & 2.0 & - & 1.3 & - & 2.0 & 3.9 & 8.7 & 15.7 & 0.9 & 3.8 \\
\hline Portulaca oleracea & 0.8 & - & 1.1 & 0.3 & 0.3 & - & 3.1 & 1.5 & - & - & 1.5 & 3.9 & - & - & 3.1 & 3.4 \\
\hline Cynodon dactylon & 8.0 & 12.6 & 5.3 & 6.4 & 7.7 & 14.2 & 8.2 & 14.4 & 1.7 & 13.1 & - & - & 11.3 & 16.1 & 3.6 & 8.4 \\
\hline Eclipta $a / b a$ & 1.1 & 0.8 & - & - & - & - & - & - & - & - & - & - & - & - & - & - \\
\hline $\begin{array}{l}\text { Alternanthera philoxero } \\
\text { ides }\end{array}$ & 1.1 & 1.6 & 4.9 & 5.1 & 4.5 & - & 1.4 & 2.6 & 3.9 & 1.9 & - & - & 1.3 & 2.1 & - & - \\
\hline A. sessilis & - & - & - & - & 0.3 & - & 3.1 & - & - & - & 1.0 & - & - & - & - & - \\
\hline Heliotropium indicum & - & - & - & - & - & 0.3 & - & - & - & - & - & - & - & - & 0.4 & 0.8 \\
\hline Amarant has viridis & - & - & - & 1.0 & - & - & - & & - & - & - & - & - & - & - & - \\
\hline Jussiaea decurrens & - & - & - & - & - & - & - & - & - & 3.3 & - & - & - & - & - & - \\
\hline
\end{tabular}

$\mathrm{T}_{1}=$ no weeding, $\mathrm{T}_{2}=$ no weeding upto 40 days after transplanting (DAT), $\mathrm{T}_{3}=$ no weeding upto $30 \mathrm{DAT}$, $\mathrm{T}_{4}=$ no weeding upto $20 \mathrm{DAT}$,

$\mathrm{T}_{5}=$ weed free through out the growing period, $\mathrm{T}_{6}=$ weeding upto $20 \mathrm{DAT}, \mathrm{T}_{7}=$ weeding upto $30 \mathrm{DAT}$ and $\mathrm{T}_{8}=$ weeding upto $40 \mathrm{DAT}$. 
Weed dry matter: Total dry matter of weeds upto 60 DAT are presented in Table 3. Dry matters of weeds were significantly influenced by different treatments. Maximum dry matters of weeds $\left(272.71\right.$ and $\left.451.15 \mathrm{~g} / \mathrm{m}^{2}\right)$ were recorded from unweeded plot in 2005 and 2006, respectively. Heavy rainfall with prevailing high temperatures during growing period favoured weed germination from soil and vigorus growth that resulted higher dry matter of weeds in 2006. Similar statement was mentioned by Bogdan (2002). The lowest dry matter of weeds were recorded from the weeded plots upto 40 DAT $\left(76.30 \mathrm{~g} / \mathrm{m}^{2}\right)$ followed by weeded upto 30 DAT in 2005, but in 2006, lower dry matter from weeding upto 40 DAT, which was closely followed by weed free throughout the growing period. There was trend to increase dry matter of weeds with the advancement of weeding time from 20 to 40 DAT. Similar trend was followed in both the years. Weeding upto 30 DAT, reduced weed dry biomass by $71 \%$ in 2005 and $72 \%$ in 2006 compared to no weeding. Further, weeding upto 40 DAT reduced weed dry biomass by $72 \%$ in 2005 and $77 \%$ in 2006 compared to no weeding or weedy check. Average over the years, maximum weed control efficiency recorded $75 \%$ from weeding upto 40 DAT followed by weed free throughout the growing season (72.46\%) and weeding upto 30 DAT (71.53\%).

Table 3. Dry matter of weeds. weed control efficiency and vine yield of Indian spinach as affected by different treatments during 2005 and 2006.

\begin{tabular}{|c|c|c|c|c|c|c|c|c|c|c|c|c|}
\hline \multirow[t]{2}{*}{ Treatments } & \multicolumn{3}{|c|}{$\begin{array}{l}\text { Dry matter of weeds } \\
\qquad\left(\mathrm{g} / \mathrm{m}^{2}\right)\end{array}$} & \multicolumn{3}{|c|}{$\begin{array}{l}\text { Weed control } \\
\text { efficiency } \\
\text { (\%) }\end{array}$} & \multicolumn{3}{|c|}{$\begin{array}{l}\text { Total vine fresh yield } \\
\text { (t/ha) }\end{array}$} & \multicolumn{3}{|c|}{$\begin{array}{c}\text { Reduction of yield } \\
\text { over weed free (15) } \\
\text { (\%) }\end{array}$} \\
\hline & 2005 & 2006 & Mean & 2005 & 2006 & Mean & 2005 & 2006 & Mean & 2005 & 2006 & Mean \\
\hline $\mathrm{T}_{1}$ & 272.71 & 451.15 & 361.93 & - & - & - & 19.21 & 4.41 & 11.81 & 74.3 & 90.9 & 82.6 \\
\hline $\mathrm{T}_{2}$ & 231.40 & 243.24 & 237.32 & 15.15 & 46.08 & 30.62 & 29.08 & 25.67 & 27.38 & 61.1 & 47.1 & 54.1 \\
\hline $\mathrm{T}_{3}$ & 173.70 & 190.74 & 182.22 & 36.31 & 57.72 & 47.02 & 54.10 & 32.19 & 43.15 & 27.7 & 33.6 & 30.7 \\
\hline $\mathrm{T}_{4}$ & 150.40 & 179.18 & 164.79 & 44.85 & 60.28 & 52.57 & 65.65 & 34.44 & 50.05 & 12.3 & 28.9 & 20.6 \\
\hline $\mathrm{T}_{5}$ & 83.90 & 109.70 & 96.8 & 69.23 & 75.68 & 72.46 & 74.82 & 48.48 & 61.65 & - & - & - \\
\hline $\mathrm{T}_{6}$ & 93.70 & 144.70 & 119.2 & 65.64 & 67.93 & 66.79 & 59.77 & 39.67 & 49.72 & 20.1 & 18.2 & 19.2 \\
\hline $\mathrm{T}_{7}$ & 80.20 & 124.20 & 102.2 & 70.59 & 72.47 & 71.53 & 71.65 & 41.83 & 56.74 & 4.2 & 13.7 & 8.9 \\
\hline $\mathrm{T}_{8}$ & 76.30 & 101.60 & 88.95 & 72.02 & 77.48 & 74.75 & 72.67 & 44.19 & 58.43 & 2.9 & 8.8 & 5.9 \\
\hline LSD (0.05) & 23.6 & 45.62 & & - & - & & 6.82 & 9.88 & & - & - & \\
\hline CV (\%) & 14.8 & 13.49 & & - & - & & 6.97 & 16.73 & & - & - & \\
\hline
\end{tabular}

$\mathrm{T}_{1}=$ no weeding, $\mathrm{T}_{2}=$ no weeding upto 40 days after transplanting (DAT), $\mathrm{T}_{3}=$ no weeding upto $30 \mathrm{DAT}, \mathrm{T}_{4}=$ no weeding upto $20 \mathrm{DAT}, \mathrm{T}_{5}=$ weed free through out the growing period, $\mathrm{T}_{6}=$ weeding upto $20 \mathrm{DAT}, \mathrm{T}_{7}=$ weeding upto $30 \mathrm{DAT}$ and $\mathrm{T}_{8}=$ weeding upto 40 DAT. 
Vine fresh yield: Yield of Indian spinach was significantly affected by different treatments (Table 3). Maximum yield of $74.82 \mathrm{t} / \mathrm{ha}$ in 2005 and $48.48 \mathrm{t} / \mathrm{ha}$ in 2006 was recorded from weed free throughout the growing period $\left(T_{5}\right)$ and it was statistically identical with yields obtained when the plots were weeded upto 40 DAT (72.67 t/ha in 2005 and 44.19 t/ha in 2006) and 30 DAT (71.65 t/ha in 2005 and $41.83 \mathrm{t} / \mathrm{ha}$ in 2006). On the contrary, yield obtained from no weeding upto 30 DAT $\left(\mathrm{T}_{3}\right)$ was significantly lowered compared with no weeding upto 20 DAT $\left(\mathrm{T}_{4}\right)$. It indicates that 20 to $30 \mathrm{DAT}$ is the sensitive stage of Indian spinach to compete with weeds. Significantly the lowest yield of 19.21 and $4.41 \mathrm{t} / \mathrm{ha}$ was obtained from unweeded check in both the years. Vigorous weed growth and severe crop weed competition drastically reduced crop yield of the control plots. However, the reduction of vine yield under unweeded plots $\left(T_{1}\right)$ was $74 \%$ in 2005 and 91\% in 2006 compared with weed free throughout the growing period $\left(T_{5}\right)$ followed by the reduction of 61 to $47 \%$ from no weeding upto 40 days after transplanting $\left(\mathrm{T}_{2}\right)$. The lowest reduction in vine yield was recorded 2.9 to $8.8 \%$ when the plots were weeded upto 40 DAT (T8), followed by 4.2 to $13.7 \%$ when weeded upto 30 DAT $\left(\mathrm{T}_{7}\right)$ in 2005 and 2006, respectively. The yield of Indian spinach was higher in 2005 than 2006 probably due to vigorous weed growth in the whole crop duration. It was also evident that the reduction in vine yield of Indian spinach was associated with an increase in the dry weight of weeds and there was a highly significant negative correlation between dry matter of weeds and vine yield of Indian spinach with r value of- 0.952 for 2005 and-0.986 for 2006, respectively. It indicates that field of Indian spinach should be kept free from weeds upto $30 \mathrm{DAT}$ to avoid yield reduction.

Table 4. Yield, cost and benefit analysis of Indian spinach as affected by different weed management practices during 2005 and 2006.

\begin{tabular}{l|c|c|c|c|c|c|c|c|c|c}
\hline \multirow{2}{*}{ Treatments } & \multicolumn{2}{|c|}{ Yield (t/ha) } & \multicolumn{2}{c}{$\begin{array}{c}\text { Gross benefit } \\
\text { (Tk/ha) }\end{array}$} & \multicolumn{2}{c|}{$\begin{array}{c}\text { Total cost } \\
\text { (Tk/ ha) }\end{array}$} & \multicolumn{2}{c|}{$\begin{array}{c}\text { Net return } \\
\text { (Tk/ ha) }\end{array}$} & \multicolumn{2}{c}{ BCR } \\
\cline { 2 - 12 } & 2005 & 2006 & 2005 & 2006 & 2005 & 2006 & 2005 & 2006 & 2005 & 2006 \\
\hline $\mathrm{T}_{1}$ & 19.21 & 4.41 & 57630 & 13230 & 43062 & 43062 & 14568 & -29832 & 1.34 & 0.31 \\
$\mathrm{~T}_{2}$ & 29.08 & 25.67 & 87240 & 77010 & 53270 & 54405 & 33970 & 22605 & 1.64 & 1.42 \\
$\mathrm{~T}_{3}$ & 54.10 & 32.19 & 162300 & 96570 & 50678 & 51812 & 111622 & 44758 & 3.20 & 1.86 \\
$\mathrm{~T}_{4}$ & 65.65 & 34.44 & 196950 & 103320 & 52460 & 53108 & 144490 & 50212 & 3.75 & 1.95 \\
$\mathrm{~T}_{5}$ & 74.82 & 48.48 & 224460 & 145440 & 53594 & 56511 & 170866 & 88929 & 4.19 & 2.57 \\
$\mathrm{~T}_{6}$ & 59.77 & 39.67 & 179310 & 119010 & 47437 & 47923 & 131873 & 71087 & 3.78 & 2.48 \\
$\mathrm{~T}_{7}$ & 71.65 & 41.83 & 214950 & 125490 & 47599 & 48409 & 167351 & 77081 & 4.52 & 2.59 \\
$\mathrm{~T}_{8}$ & 72.67 & 44.19 & 218010 & 132570 & 49868 & 51002 & 168142 & 81568 & 4.37 & 2.60 \\
\hline
\end{tabular}
weeding upto $30 \mathrm{DAT}, \mathrm{T}_{4}=$ no weeding upto $20 \mathrm{DAT}, \mathrm{T}_{5}=$ weed free through out the growing period, $\mathrm{T}_{6}=$ weeding upto $20 \mathrm{DAT}, \mathrm{T}_{7}=$ weeding upto $30 \mathrm{DAT}$ and $\mathrm{T}_{8}=$ weeding upto 40 DAT. 
Cost benefit analysis: Economic analysis of different weed management practices of Indian spinach production was done (Table 4). Highest gross return was obtained from weed free throughout the growing period $\left(T_{5}\right)$ in both the years. Gross return was decreased with the advancement of delay weeding (20 to 40 DAT) and same for weed control. Similar trend was followed in the case of net return. Though higher benefit was recorded from $T_{5}$, but high cost was involved in this treatment. As a result, lower BCR was recorded in $T_{5}$ than $T_{7}$. Maximum BCR (4.52) was obtained from $\mathrm{T}_{7}$ in 2005, but almost similar BCR (2.60) was recorded in 2006. On an average, higher BCR (3.55) was recorded from $\mathrm{T}_{7}$ (weeding upto $30 \mathrm{DAT}$ ) followed by $\mathrm{T}_{8}$ weeding uplo 40 DAT. Irom economic point of view, it reveals that Indian spinach plot should be weed free upto 30 DAT.

\section{Conclusion}

Based on the two years' data, it was concluded that the critical period for crop weed competition of Indian spinach lies within 20 to 30 days after transplanting. Hence, Indian spinach field would be kept weed free upto 30 days after transplanting and two times hand weeding would be necessary within 30 DAT for maximum benefit.

\section{References}

Anonymous. 2000. Puishaker utpadon projukti. In Shabjir unnato jat o utpadon paddoti (Bengali). S,M.M. Hossain. Ed. Horticulture Research Center, BARI, Gazipur. p.46.

Bogdan,I. 2002. The summer rainfall impact to the weediest degree in maize crops. Agricultura 11: 18-23.

Nicto, J., M.L. Brando and J.T. Gongales. 1968. Critical period of crop growth cycle for competition from weeds. PCNS 14: 159-166.

Martin, S.G., R.C. Van Acker and L.F. Friesen. 2001. Critical period of weed control in spring canola. Weed Sci. BioOne 44: 326-333.

Porwal, M.K. and M.M. Singh. 1993. Efficacy of herbicides for weed control in cauliflower. Ind. J. Weed Sci. 25: 55-60.

Singh. M.P. and K.P. Singh. 1994. Effect of crop weed competition on growth and yield of kharif onion. Ind. J. Weed Sci. 26: 18-21.

Singh, C.M., S.D. Singh and S. Kumar. 1993. Study on the weed management in okra. Ind. J. Weed Sci. 25: 92-94.

Tiwari, S.K., B.P. Jam, V.S. Bramchari, M.M. Pujari and S.P. Singh. 1984. Integrated method of weed control in okra (Abelmoschus esculenlus (L.), Moench). Annual Conf. md. Soc. Weed Sci. Feb. 27-28. p-70. 